\title{
A Provincia Jesuitica do Paraguai e o estilo jesuítico-guaraní de fazer missão
}

The Jesuit Province of Paraguay and the Jesuit-Guaraní style of doing mission

Erneldo Schallenberger*

\section{Resumo}

Na Província Jesuítica do Paraguai se desenvolveu um processo de evangelização e de socialização no Guairá, no Itatim e no Uruguai que definiu um estilo jesuítico-guarani de fazer missão, fundado em relações horizontais e dialógicas, sem renúncia à apologética da salvação, e no princípio da libertação (do estado da natureza, do demônio, dos inimigos escravocratas) enquanto possibilidade de conversão e de constituição de um território de missioneiro. O recuo da fronteira do território missioneiro em construção, consubstanciou uma maior unidade territorial, construída a partir da solidificação da defesa, das relações de poder e da organização interna do complexo missioneiro dos trinta povos da bacia do Prata.

Palavras Chave: Evangelização - socialização - relações horizontais - missão.

\begin{abstract}
In the Jesuit Province of Paraguay developed a process of evangelization and socialization in Guairá, in Itatim and Uruguay which defined a Jesuit-Guarani mission style, based in horizontal and dialogical relations, without renouncing the apologetics of salvation, and the liberation principle (the state of nature, the devil, the slavocrats enemies) as possibility of conversion and establishment of a mission territory. The recoil of the mission territory under construction provides a larger territorial unit, built

\footnotetext{
* Pós-Doutorado em História. Docente do CCHS e dos Programas de Pós-Graduação em Ciências Sociais, Desenvolvimento Regional e Agronegócio e Sociedade, Cultura e Fronteiras da Universidade Estadual do Oeste do Paraná (UNIOESTE). Membro do Comitê Científico de Ciências Humanas, Sociais e Jurídicas da Fundação Araucária e do Grupo de Pesquisa UNIOESTE/CNPq Cultura, Fronteiras e Desenvolvimento Regional.
} 
from the solidification of defense, power relations and the internal organization of the mission complex from the thirty nations from La Plata basin.

Key Words: Evangelization, socialization, horizontal relations; mission

Recibido: 15 de junio de 2014

Evaluado: 8 de julio de 2014 
O complexo missioneiro jesuítico da antiga Província do Paraguai sugere uma possível leitura centrada nas categorias relacionais homem, tempo e espaço e uma hermenêutica que considera a dinâmica sócio-espacial a partir dos pares teóricos das verticalidades e das horizontalidades, tendo em vista a interpretação das culturas, dos usos políticos e econômicos do território e das populações. Para Santos ${ }^{1}$ a dimensão horizontal corresponde às atividades e ações que possibilitam a estruturação da vida social. Já as verticalidades correspondem aos vetores de uma racionalidade superior e do discurso pragmático dos setores hegemônicos. Na dimensão vertical o território é usado como recurso e espaço de poder, onde o político, o religioso e o econômico assumem expressões sociais e culturais que procuram cimentar estruturas e dinâmicas societárias voltadas para o atendimento de formas específicas do uso dos recursos humanos e naturais para a satisfação de interesses exteriores à região sobre a qual são projetados.

No tempo da conquista da América, as colônias eram vistas como espaços receptores de políticas e de ações que potencializavam a verticalização das relações sociais e de poder. No caso da Espanha, os recursos do Estado foram canalizados para a guerra da conquista, para as expedições exploratórias, para a apropriação de territórios e para a constituição de bases societárias voltadas para alimentar as demandas do sistema colonial. Na perspectiva das verticalidades, o Estado era detentor da missão superior e humanitária da civilização e da cristianização dos povos conquistados. A ocupação e a dominação colonial acabavam interferindo na estrutura das sociedades tribais, isto é, no seu habitus, aqui entendido como expressão do modo de ser constituído a partir de vivências num tempo de longa duração, ou seja, como produto de uma aquisição histórica, segundo a acepção de Bourdieu².

Os espaços conquistados no processo de expansão colonial ibérica refletem ações conduzidas de diferentes formas e motivações para a fixação do território. Em referência aos conceitos usados por Maria Luísa Leal ${ }^{3}$, pode-se dizer que no espaçooutro se encontrava o radicalmente outro, visto, por vezes, como exótico e antropologicamente interessante, quando não reduzido a uma exterioridade observada em condições infra-humanas.

As diferentes regiões conquistadas revelaram particularidades, onde o território passou a ser constituído a partir das especificidades do espaço, caracterizado pelos recursos naturais e, sobretudo, pelas populações nativas que o habitavam. Destarte, a formação do espaço comportou ações conduzidas pelos agentes da conquista.

O movimento da conquista ensejou, também, a horizontalização das relações, buscando, além da exploração econômica, o uso social do território e a incorporação das populações nativas no sistema colonial. Esta horizontalidade teve expressão substancial com o estabelecimento das obrages no Peru, a partir de 1554, que se dedicaram, entre outras atividades, à fabricação têxtil e à expansão do sistema de encomendas, gerando uma progressiva absorção de mão de obra indígena e maior circulação de bens produzidos na colônia. Em regiões mais distantes dos pólos de exploração mineral e das rotas comerciais a horizontalidade se impôs como condição para a apropriação territorial. Promoveu de certa forma o reconhecimento de alteridades ao mesmo tempo

\footnotetext{
${ }^{1}$ Santos, 1996: 206.

2 Bourdieu, 1982: 183 ss.

${ }^{3}$ Leal, 2001.
} 
em que desvelou fronteiras culturais em relação às bases societárias, às práticas decorrentes dos espaços vividos e das representações simbólicas.

A eminente necessidade de lançar as bases da colonização nestas regiões mais distantes teve um desdobramento de ações conduzidas que evidenciam a dialética da verticalidade e da horizontalidade. De um lado os interesses da coroa se expressaram através do estabelecimento política de "merced y encomiendas", em base a um conjunto de leis e normas para a sua concessão e funcionamento, e de outro, os colonos se viram na contingência de interagir com as populações nativas para dispor da sua força de trabalho e para a constituição de bases societárias que pudessem atender suas demandas tanto biológicas quanto socioeconômicas. A crescente necessidade dos colonos terem índios tributários para a manutenção das vilas e para suprir os impostos da Coroa foi absorvendo um contingente sempre maior de braços indígenas para a exploração das riquezas naturais e para as atividades agropastoris, tirando-os do seu natural modo de vida. No Paraguai, a política do estabelecimento das encomiendas foi instaurada a partir de 1556, nas imediações de Assunção e no Guairá, e, com ela, a instituição do serviço pessoal foi gerando um desgaste progressivo nas relações de parceria, na medida em que a reciprocidade se tornou desfavorável aos povos indígenas. Os documentos históricos relativos à época, sobretudo os da vertente jesuítica, passaram a caracterizar o universo das encomiendas como campo de conflitos onde forças entrecruzadas se sobrepuseram, desafiando as estruturas de poder hegemônico. A missão religiosa se apresentou, neste contexto, como mediação pertinente para o uso social do território e para incrementar relações horizontais que pudessem viabilizar o ideário civilizador e cristão não atendido pelos encomendeiros. É por esta razão que ela centrou, num primeiro instante, sua ação evangelizadora nas proximidades das encomiendas.

A conquista espiritual da América esteve fundada na concessão dada pelo papa Alexandre VI através da bula Inter Coetera, de 4 de maio de 1493, pela qual os reis católicos passaram a ter a prerrogativa de organizarem a ação missionária, com especial atenção voltada à seleção dos evangelizadores ${ }^{5}$. A bula Veritas Ipsa do papa Paulo III, dada em 1537, trata do reconhecimento da dignidade humana dos povos nativos e da estratégia de sua evangelização, expressos no seguinte teor:

[...] determinamos, e declaramos, que os ditos Índios, e todas as mais gentes que daqui em diante vierem à noticia dos Cristãos, ainda que estejam fora da Fé de Cristo, não estão privados, nem devem sê-lo, de sua liberdade, nem do domínio de seus bens, e que não devem ser reduzidos a servidão. Declarando que os ditos índios, e as demais gentes hão de ser atraídas, e convidadas à dita Fé de Cristo, com a pregação da palavra divina, e com o exemplo de boa vida ${ }^{6}$.

\footnotetext{
${ }^{4}$ As Mercedes são as doações reais de bens, de seu patrimônio ou da coroa, e títulos em troca do apoio dado à alta nobreza ou ao clero pelo pagamento de algum serviço. A Encomienda não implicava a propriedade de terra, mas só a sua posse e o direito a receber tributo em espécie e o trabalho dos índios, que, em compensação, deveriam ser doutrinados na fé cristã (Zavala, 1940).

${ }^{5}$ Mateos, 1944: 166.

${ }^{6}$ http://www.montfort.org.br - 28 de janeiro de 2008.
} 
A partir daí, uma série de expedientes pontifícios e reais passaram a regular o envio de missionários, beneficiando, sobretudo, as grandes ordens religiosas como as dos franciscanos, dominicanos, agostinianos e carmelitas.

Na Espanha, a Companhia de Jesus, reconhecida pelo para Paulo III em 1540, mereceu algumas resistências em relação ao envio de missionários para a evangelização do Novo Mundo, muito em função do diminuto número de seus membros e da desconfiança nela depositada pelos governantes de lhes devotarem fidelidade. Com a entrada dos primeiros jesuítas no Brasil em 1549, liderados por Manuel da Nóbrega, os inacianos empreenderam a sua ação missionária através da fundação de colégios, do aldeamento e da "pacificação" dos índios, o que lhes granjeou confiança em torno dos seus métodos de evangelização ${ }^{7}$. O trabalho dos jesuítas do Brasil adquiriu visibilidade e passou a ser desejado pelas instâncias do poder político e eclesiástico da colônia espanhola, diante do que Felipe II expediu Cédula Real, em março de 1566, autorizando a entrada da Companhia na América espanhola. De imediato a Companhia providenciou o envio de missionários para a Flórida, em 1566, para o Peru, em 1567, para o reino do México, em 1572, e para Tucumã em $1586^{8}$.

A intensificação da conquista espiritual das fronteiras coloniais da região do Rio da Prata ganhou força no período da unificação das coroas da Espanha e Portugal, quando da Província Jesuítica do Brasil partiu a iniciativa de se enviar missionários para o Paraguai. O pleito dirigido ao geral da Companhia para que intercedesse junto ao monarca espanhol para liberar a entrada dos jesuítas no Paraguai foi reforçado com a iniciativa do bispo de Tucumã, Francisco de Vitória, que contatou a Companhia de Jesus em Lima e o provincial do Brasil, José de Anchieta, para que enviassem padres para a missão em sua jurisdição eclesiástica. Atendidos os propósitos evangelizadores, os jesuítas provenientes do Brasil se encontraram com os vindos do Peru e, em 1588, foram enviados para Assunção. A diversidade de proveniências e de origem dos missionários (portuguesa, espanhola, irlandesa) certamente conferiu à missão do Paraguai uma característica de universalidade, pelo menos difusa e ambígua em relação à centralidade do poder político ${ }^{9}$. Em termos de jurisdição eclesiástica, travaram-se contendas em torno do pertencimento da missão do Paraguai às províncias do Brasil ou do Peru, segundo a historiografia jesuítica capitaneada por Serafim Leite (1938) e Pablo Hernandez (1913).

O P. Diego de Torres entendia que era pertinente unir o reino do Chile e a comarcas de Tucumã e do Paraguai, mediante a divisão da província do Peru. Recebeu contestação dos seus pares que se opuseram a divisão daquela província, alegando que pessoas influentes de Tucumã e do Paraguai se queixavam do abandono de extensas regiões em prejuízo das almas e que a divisão atendia tão-somente interesses particulares do padre Torres. O padre Nicolas del Techo ${ }^{10}$, revela que os interesses contrariados tiveram sua razão fundada na inexistência de cidades populosas naquelas regiões que pudessem acolher a fundação de colégios. Os colégios e suas fazendas representaram as estruturas de poder mais fortes da Companhia para se enraizar nos espaços da conquista colonial. Sem eles, a ação da Companhia teria que se concentrar

\footnotetext{
${ }^{7}$ Leite, 1938.

${ }^{8}$ Astrain, 1913, V. IV; Techo, 2005: 70.

${ }^{9}$ Aguilar, 2002: 122.

10 Techo, 2005: 150 e ss.
}

9 Erneldo Schallenberger. A Provincia Jesuitica do Paraguai e o estilo jesuítico-guaraní ....: 5-23 
nas relações horizontais de conquista espiritual e de evangelização dos nativos. As divergências em relação às formas de inserção da Companhia nos novos espaços de missão demandaram muitas consultas ao geral da ordem, P. Cláudio Aquaviva, que, por fim, decidiu, em 1607, fundar a nova Província do Paraguai, desmembrada da do Peru.

A Província Jesuítica do Paraguai se estendeu por todo o sul do continente, com exceção do Chile. Compreendia territórios dos atuais países do Paraguai, Uruguai, Argentina, Bolívia e sul do Brasil. Com a instalação da nova província, em 1608, a Companhia de Jesus mudou sua estratégia de ação missionária, muito em função das circunstâncias definidoras do perfil sociocultural da região. O núcleo colonial de Assunção nasceu fundado na aliança espano-guarani e se desenvolveu em base a este vínculo, com presença marcante dos filhos da terra ${ }^{11}$. A introdução do sistema de encomiendas aproximou ainda mais os colonos dos índios, mesmo que desta aproximação resultassem conflitos. Nas vilas e aldeias do Paraguai, distantes entre si, "os costumes dos espanhóis em nada se diferençavam dos praticados pelos índios; os matrimônios se contraiam segundo os antigos usos do país e o amancebamento era coisa freqüente" 12 .

Frente a esta realidade sócio-antropológica e diante do apoio manifesto do governador da área do rio da Prata (1602-1609) Hernandarias [Hernando Arias de Saavedra] que era filho da terra e havia recebido do rei da Espanha o encargo da conversão das províncias ainda não submetidas sem o emprego de armas e somente com missionários, os jesuítas valeram-se da estratégia do apalavramento e da aliança com os principais das tribos para empreender sua obra missionária. O apalavramento requeria, sobretudo, a apropriação da linguagem do outro, a conversão simbólica desta linguagem e a recriação de uma nova linguagem que possibilitasse uma relação dialógica entre missionários e índios.

Entre os Mbyá-Guarani do Guairá, a linguagem revela, segundo os textos míticos ordenados por León Cadogan ${ }^{13}$, a origem da porção divina da alma humana e a palavra é a expressão da manifestação da alma. Para os Guarani Nhandéva contemporâneos, do Tekohá Añetete do oeste do Paraná, os mitos explicam as vidas e as vidas se transformam em mitos. As referências de Montoya ${ }^{14}$ de que "nunca tiveram eles ídolos, embora o demônio lhes estivesse impondo a idéia de venerarem os ossos de alguns índios, que em vida haviam sido magos famosos [...]" e que "tinham por doutrina muito certa que no céu haja um tigre ou cachorro muito grande, que, em certos fatos de raiva, devora o sol e a lua" revelam o contraditório, pelo qual um dos fundamentos da religião guarani deriva da possibilidade da encarnação dos espíritos dos mortos e, inclusive da alma dos animais nos indivíduos ${ }^{15}$. Como de modo geral os Guarani não se entendem como indivíduos e sim como pertencentes a uma família extensa, ou coletividade $^{16}$, quando se distanciam desta coletividade demonstram que estão possessos de uma alma animal, ou seja, de um espírito inferior.

\footnotetext{
${ }^{11}$ Mora Mérida, 1971: 74.

12 Techo, 2005: 195.

${ }^{13}$ Cadogan, 1959: 19 ss.

${ }^{14}$ Montoya, 1985: 52 e 53.

${ }^{15}$ Cadogan, 1959: 39 ss.

${ }^{16}$ Caleffi, 2002: 23.
} 
As fronteiras culturais interpostas pelo contato de dois mundos de culturas diferentes desafiaram os missionários a construírem a partir do fenômeno religioso uma nova linguagem. O jesuíta missioneiro aparece assim como o criador de uma linguagem religiosa fundada na apologética da doutrina cristã, que, sem renúncia à dogmática, busca estabelecer interface como a cultura indígena. Para Cristina Pompa ${ }^{17}$ "a linguagem religiosa é o terreno de mediação, onde cada cultura, a ocidental e a indígena, encontra o sentido da 'diversidade' da outra”. A linguagem religiosa, expressa em palavras, sinais, ritos e símbolos, era portadora de significados que fizeram aflorar os elementos de distinção e requeriam uma relação inter-cultural, muitas vezes negociada, para viabilizar a construção de um novo espaço sociocultural.

A possibilidade de encontrar elementos que revelam uma aproximação entre as religiões mítica dos Mbyá-Guarani e a cristã quanto à origem criadora do universo a partir de um ser originário superior jamais pode ocultar que os fundamentos ontológicos e cosmológicos são radicalmente divergentes, uma vez que uma se apóia no mito criador associado às fontes e às forças emergentes da natureza e dos sentidos que dela derivam enquanto que a outra busca na racionalidade da fé a distinção entre a natureza divina sobrenatural e a ordem natural. Como não pertencentes à ordem sobrenatural (transcendente), os deuses imanentes da natureza dos guaranis não se constituíam para os jesuítas em divindades ${ }^{18}$, mesmo que admitam que entre eles houvesse “conhecimento de um Deus criador de todas as coisas e que está no céu, mas ao lado disto cultivam outras coisas bárbaras como pessoas que não tem a luz da fé e dizem que podem mandar as almas dos seus defuntos para o céu [...]"19. Destituídos de sua religiosidade original, os índios eram tidos como pagãos, não professos do Deus verdadeiro e sem lei, tanto no terreno da fé quanto no da ordem moral e política. A linguagem missionária cristã era portadora dos símbolos do sagrado e do divino que remetiam ao plano da salvação revelado, pelo qual se projetava a plenitude da realização humana para além do espaço e tempo vividos para uma ordem subjetiva sobrenatural.

É importante observar que certos conceitos e categorias lingüísticas, canonizados pela linguagem cristã, foram invariavelmente mantidos na nova linguagem, pelo que os missionários, nas novas situações vivenciadas, procuraram acomodar a realidade ao conjunto ortodoxo dos conceitos e significados estabelecidos. O mesmo pode ser dito em relação à linguagem política ou social produzida pelos setores hegemônicos da sociedade ibérica. Esta postura hermenêutica em relação aos documentos que guardam fragmentos da memória da conquista e da colonização da América encontra reforço na advertência de Reinhart Koselleck ${ }^{20}$, que assevera: "só então posso perguntar às fontes textuais o que elas indiciam em relação à história concreta e que qualidades possuiriam para co-produzirem história enquanto textos”.

A imersão no mundo da cultura indígena [guarani] conferiu à missão do Paraguai características que vão além dos cânones estabelecidos pela Corte e pela Companhia de Jesus, apesar de se apoiar nas orientações emanadas destas duas instâncias de poder. Os territórios indígenas eram circunscritos pela liderança dos principais (caciques) das tribos e simbolizavam os espaços desembaraçados de

\footnotetext{
${ }^{17}$ Pompa, 2001: 177.

${ }^{18}$ Montoya, 1985: 52 ss.

${ }^{19}$ Cortesão, 1951: 346.

${ }^{20}$ Koselleck, 1992: 134-146.
} 
circulação. A conquista espiritual requereu, sobretudo, o domínio da vontade de querer do cacique, para que com ele o seu território simbólico pudesse ser transformado em terra de missão. Com isto, a conquista do outro assumiu o sentido do reconhecimento da alteridade, onde a evangelização e a conversão só se fariam possíveis mediante a fusão de elementos espirituais e materiais das duas culturas em contato, sem que uma abdicasse de todo da sua singularidade em favor da outra.

O Guairá, revelado pelos exploradores ibéricos, emerge para os agentes da conquista e da colonização como região estratégica, não só como caminho de ligação entre Assunção, São Vicente e o litoral atlântico, para desviar dos desembaraços das frentes da conquista e do comércio no rio da Prata, mas, também, sob o ponto de vista demográfico, com uma população dada à prática da horticultura em um espaço de terras férteis, cortadas por rios navegáveis. Apresentava-se para as autoridades coloniais hispânicas como uma fronteira de colonização, sobretudo, para o desenvolvimento de atividades agrícolas, para as portuguesas como fronteira aberta para o descimento e recrutamento de mão de obra para viabilizar a economia da capitania de São Vicente e abastecer a agroindústria canavieira de mão de obra e para os jesuítas, nomeadamente Cristóvão de Gouveia, visitador de Portugal, Manuel da Nóbrega, da província do Brasil, e Diego de Torres, da província do Peru, como vasto campo de missão ${ }^{21}$.

O Guairá se constitui em uma fronteira múltipla de manobra das forças de conquista do colonialismo e dos interesses dos seus agentes derivaram as formas de apropriação do seu espaço. Como espaço de projeção para o futuro colonial, a decisão de fundar vilas aparece nas fontes textuais, tanto da vertente espanhola quanto portuguesa, como estratégia de fixação de povoamento e ocupação territorial da grande região do $\operatorname{Prata}^{22}$. Segundo estas fontes, a colonização do Guairá teria partido da determinação de Domingo Martinez de Irala, governador do Paraguai nos períodos de 1538-1540 e de 1544-1556. Irala percorreu a região em 1544 para levantar o potencial humano e dos recursos naturais, diante do que decidiu pelo seu povoamento, com a fundação da Vila de Ontiveros, em 1554, a 6 km acima dos saltos do Guairá, segundo Jaeger (1957). A estratégia de Irala de fundar vilas nos caminhos que levam ao Brasil e ao litoral atlântico revela a preocupação com isolamento de Assunção e com a efetiva ocupação territorial por colonização, baseada no sistema de encomiendas, pelo qual a população nativa seria submetida e distribuída aos colonos espanhóis. Os caminhos referidos eram entrecruzados pelas populações nativas, espanhóis e portugueses. Portugueses haviam chegado e se estabelecido em Assunção e espanhóis em São Vicente, de sorte que a fixação dos povoados no Guairá facilitou o comércio incipiente e o contrabando entre os dois núcleos de colonização ${ }^{23}$.

No início da monarquia dual, os estatutos dos reinos da Espanha e de Portugal foram mantidos. Intensificou-se a regulação do processo de povoamento, principalmente no que diz respeito à forma de incorporação das populações nativas ao

\footnotetext{
${ }^{21}$ ARSI, Lus. 68: 408-409; Leite, 1940: 27; Techo, 2005: 163.

22 Guzmán, 1980; Cortesão, 1951: 72.

${ }^{23}$ Quarleri, 2009: 74 ss.
} 
sistema colonial. Da vertente portuguesa, o núcleo de povoamento de São Vicente, constituído em 1532, buscou a sua inserção produtiva na economia colonial através da tentativa da descoberta de riquezas naturais e do desenvolvimento de atividades agroindustriais que requeriam a crescente absorção da mão de obra nativa. Sérgio Buarque de Holanda (1957) sublinha que a interiorização territorial de São Vicente rompeu fronteiras e promoveu uma miscigenação cultural responsável por um tipo social dotado de mobilidade e de espírito de aventura. A busca de novas riquezas no interior é atribuída pelo historiador à ausência de uma estrutura econômica capaz de favorecer a sua inserção produtiva na dinâmica do sistema colonial e encontra guarida na política do governador São Paulo, Luís de Souza, que custeou o recrutamento de índios do sertão do Guairá para ajudar a trabalhar nas atividades econômicas dos portugueses $^{24}$.

Na vertente espanhola, o Guairá se constituía em uma região intermediária entre Assunção e São Vicente e contava, no início da unificação das coroas, com duas vilas, Cidade Real do Guairá (1557) e Vila Rica do Espírito Santo (1570), povoadas respectivamente por aproximadamente 30 e 100 colonos, pelas informações contidas na carta do governador Hernandarias, datada em $1607^{25}$. No mesmo expediente o governador destaca que "estes dois povoados têm em seu distrito uma grande soma de índios que, segundo é público, creio sejam mais de cento e cinqüenta mil, os quais se dirigem de muitas partes a estes povoados de paz e servem como e quando lhes parece, porque os espanhóis não reúnem força para poder conquistá-los e nem sujeita-los”. As frágeis relações humanas e o isolamento dos povoados do Guairá em relação ao Porto de Buenos Aires são referidos pela documentação com fatores da pobreza ${ }^{26}$. Soma-se a isto a restrição ao comércio com São Vicente e a proibição do comércio da erva mate, principal produto do extrativismo local.

A mobilidade fronteiriça dos vicentinos e as dificuldades encontradas pelos colonos espanhóis de estabelecer relações estáveis com as populações nativas fizeram com que Hernandarias solicitasse a coroa autorização para que do Brasil viessem alguns portugueses para percorrer a província do Guairá, acalmar os índios e ir reduzindo-os. Assevera, contudo, "para lo que toca a darles doctrina me parece sería de gran importância que mandase Vuestra Merced que de Brasil entrasen por San Pablo siquiera seis padres de la compañía de jesús, que harían gran fruto como lo hicieron dos que mucho tiempo estuvieron en aquela província, que tabajan con cuidado y buen ejemplo (...)"27. A solicitação do governador teve desdobramentos importantes, uma vez que a estratégia de incorporar o território e reduzir os índios ao império dual colocou frente a frente atores sociais impulsionados por demandas políticas conflitantes e movidos por interesses divergentes. Enquanto os colonos espanhóis procuravam viabilizar as encomiendas, e para tal tiveram apoio inicial dos missionários franciscanos e jesuítas, os paulistas organizaram bandeiras para descobrir metais preciosos e recrutar mão de obra para as fazendas portuguesas, desde $1585^{28}$. Não raro índios do sertão reunidos em

\footnotetext{
${ }^{24}$ AGI, Estante 74, Cajón 6, Legajo 21.

${ }^{25}$ AGI, Charcas 27, R. 8, N. 37.

${ }^{26}$ AGI, Charcas 27, R. 8, N. 22.

${ }^{27}$ Carta de Hernandarias, 1607, AGI, Charcas, 27, R. 8, N. 37.

${ }^{28}$ Luis, 2004: 352.
} 
malocas e dos que integravam forçadamente as bandeiras se refugiavam nas encomiendas e depois eram resgatados pelos bandeirantes.

A estratégia de entregar a redução dos índios da Província do Guairá aos missionários da Companhia de Jesus pode ser apreendida como uma forma de recorrência ao poder coercitivo da religião e da moral cristã para dar conta dos desmandos oriundos das relações conflitantes entre índios, colonos e bandeirantes. A decisão de reunir os índios dispersos em povoados e a fundação das primeiras reduções, Nossa Senhora de Loreto (1610) e Santo Ignácio (1611), seguiu a orientação do provincial do Paraguai, Diego de Torres Bollo, que na instrução para todos os missioneiros do Guairá, Paraná y Guaycurús (1610), admoestou que os religiosos mantivessem o fervor e tratassem os espanhóis e os maloqueiros com prudência, para ganhar a todos ${ }^{29}$. No início, houve certa cumplicidade entre missionários e colonos, na tentativa de dar maior estabilidade às encomiendas. A tolerância se estendia, também, aos bandeirantes, que encontravam nos índios reduzidos a possibilidade de atraírem parentes. Pelo informe do governador Antonio de Añasco (1611), reproduzido por Jensen (2009, 186-188), esta tática de atrair parentes era usada pelas bandeiras, que se serviam, com o consentimento dos padres, de caciques das aldeias jesuíticas de São Paulo, muitas vezes naturais do Guairá, para tal fim. Estabeleceram-se relações horizontais que intensificaram a ligação dos núcleos de povoamento espanhol com o de São Vicente. Estas relações dificultaram o modo de fazer missão dos padres da Companhia de Jesús, segundo a memória expressa nos documentos da época ${ }^{30}$.

$* * *$

O modo de fazer missão implicava em reduzir os índios, com a adesão dos caciques, num novo espaço de vivência e convivência, modificar hábitos, costumes e práticas culturais e pregar a fé cristã, introduzindo símbolos, sinais e ritos em substituição aos cultivados. As cartas dos missionários ${ }^{31}$ revelam que a destituição da liderança espiritual tradicional representava de certo modo e ao mesmo tempo a desconstituição do discurso mítico-religioso. Para conseguir a acomodação da nova realidade aos conceitos e categorias da linguagem cristã, Montoya sublinha que:

(...) fundamos uma escola de ler e escrever para a criançada e juventude. Fixou-se um tempo de uma hora pela manhã e outra à tarde, para que todos os adultos viessem à catequese ou doutrina. Ainda que nelas e em todos os sermões dominicais tratássemos com toda a clareza os mistérios da nossa santa fé e os preceitos divinos, quanto ao sexto mandamento por ora guardamos, contudo, silêncio em público. Era para que não murchassem aquelas plantas tenras e para que não se tornasse odioso o Evangelho, embora instruíssemos da maneira mais evidente possível aos que se achavam em perigo de vida ${ }^{32}$.

\footnotetext{
${ }^{29}$ Hernández, 1913: 580-589.

${ }^{30}$ Montoya, 1985; Nicolas Duran Mastrilli, Justo Mancilla e Simão Masseta, apud Cortesão, 1951: 203 ss. e 310 ss.

${ }^{31}$ Cortesão, 1951.

${ }^{32}$ Montoya, 1985: 56.
} 
A apreensão lingüística da realidade concreta vivenciada pelos índios, que não separam a vida em esferas distintas, revela o modo como os missionários expressavam conceitos ortodoxos em relação à alteridade diferenciada e diferenciadora dos mundos da cultura em contato. O freio da rígida moral cristã associava as práticas sociais e culturais indesejadas à desonestidade e ao estado de pecado. Para o missionário do Guairá, “era forçoso apresentar-lhes o ensino cristão sobre o matrimônio e a unidade com uma mulher para o homem nesta instituição cristã". E, referindo-se a um cacique na redução de Santo Inácio, sublinha que ele "era desonesto em extremo, porque tinha um grande número de concubinas, consentindo-o e até fomentando-o sua falsa mulher. Chegamos a batizar oito crianças, filhos seus e safra daquele ano. Todos se tornaram não pouco felizes, porque morreram em seguida a seu batismo"33.

A produção textual de Montoya e de outros missionários do Guairá é farta de relatos que tratam elementos e valores comportamentais da cultura guarani, dos embates vivenciados nas fronteiras culturais e dos desafios para a constituição de um território missioneiro. Um dos problemas fundamentais para a constituição de um território missioneiro era a questão da ascendência sobre os índios, disputada entre encomendeiros, bandeirantes e jesuítas ${ }^{34}$. O provincial do Paraguai, Nicolas Duran Mastrilli $^{35}$, assevera que inicialmente os padres da Companhia de Jesus necessitaram dos colonos da Cidade Real do Guairá para a organização das reduções de Loreto e Santo Inácio e que:

O maior trabalho que os índios destas duas reduções tem é que estão dedicados para servir os espanhóis da Cidade do Guairá, que conforme as conquistas passadas e as concessões dadas pelos governadores tem entre eles repartidos estes povoados de modo que tantos servem a um espanhol, tantos a outro, conforme os méritos e concessões alcançadas; cada índio tem, pois, a obrigação de servir ao espanhol que chamam de vecino encomendero dois meses e como os espanhóis são pobres querem servir-se destes índios durante todo o ano, como muitos o fazem de fato, mas os padres, procurando olhar para as suas ovelhas como bons pastores, os defendem quanto podem, procurando que não sirvam mais do que manda o $\mathrm{Rei}^{36}$.

A intensificação da exploração do trabalho indígena pelos colonos e a ação de recrutamento de mão de obra no Guairá pelos bandeirantes motivaram um novo discurso dos membros da Companhia de Jesus e das autoridades coloniais em relação ao índio do Guairá. Ao invés de bárbaros infiéis passaram a ser considerados ingênuos e pueris predestinados ao império da fé e da coroa, aos quais se deveria proteção para colocá-los em estado de liberdade ${ }^{37}$. Convergiram, neste sentido, os interesses verticais

\footnotetext{
${ }^{33}$ Montoya, 1985: 57.

${ }^{34}$ Schallenberger, 2010: 31-50.

${ }^{35}$ Cortesão, 1951: 214-216.

${ }^{36}$ Cortesão, 1951: 215.

${ }^{37}$ Montoya, 1985: 240 ss.
} 
de preservação do potencial humano para o futuro colonial. Os padres, a exemplo do parecer exarado por Diogo Gonçalves em $1610^{38}$, começaram a se posicionar contra o serviço pessoal e contra as malocas promovidas pelos bandeirantes e pelos encomendeiros para recrutar e submeter à força os nativos. Em base às orientações do superior da Companhia, o provincial do Paraguai, Diego de Torres, ordenou em 1611 que o serviço pessoal dos índios fosse progressivamente abolido nos colégios ${ }^{39}$. A nomeação de Francisco de Alfaro para visitador das governações de Tucumã e Rio da Prata e o conjunto de ordenações que previam a proibição do serviço pessoal foram decisivas para o Guairá. Em 1612 Alfaro delegou aos padres da Companhia a pregação contra o serviço pessoal ${ }^{40}$.

O conflito de interesses entre encomendeiros e missionários começou a evidenciar as contradições do próprio sistema colonial. Hernandarias imaginava as missões do Guairá como instâncias de apoio para normalizar as relações entre encomendeiros e índios, visando incrementar o povoamento da região ${ }^{41}$. O informe de um jesuíta anônimo, datado em $1620^{42}$, assinala que os colonos espanhóis eram numericamente pouco representativos, inconsistentes em seus empreendimentos, inimigos do trabalho, não obedeciam às ordenações de Alfaro, viviam em base as trocas mercadorias e da maloca de índios. Carlos E. Romero Jensen (2009) reproduziu um conjunto documental que revela que os encomendeiros passaram a se opor veementemente à pregação dos jesuítas, uma vez que a abolição do serviço pessoal inviabilizaria a sua atividade econômica e permanência no Guairá. Alertaram que se:

Vuestra Alteza no remedia esta fuerza cometida de los padres de la Compañía mandando que a su costa restituyan los indios naturales a esta Ciudad encomendados nos todos perecemos y su majestad perderá esta su Ciudad y la Villa Rica que la misma calamidad le alcanza com ellos debem avisar y nos ni fuerza tenemos para podermos mudar ni hay cura ni sacerdote ninguno que con nos quiera asistir porque no solamente llevan los indios de esta Ciudad pero con todas las otras doctrinas encomendadas al ordinario coladas por el padronazgo real $[\ldots]^{43}$.

Alegaram ainda que passaram a sofrer a ação dos bandeirantes que fazem malocas e promovem a dispersão dos índios e

[...] han llegado hasta la Villa Rica del Espírito Santo a destruir las “ 'sde los vecinos de ellas y querendo los vecinos de la Villa Rica defender sus indios encomendados sucedió haber muertes así en los portugueses como en los españoles y naturales la causa a sido los Padres de la Compañía que asistem en estas reducciones de Pirapó y Ipaumbuçu por doctrinantes por haber recogido en las dichas reduciones los índios que huyen de la Villa de San Pablo para estas partes $[\ldots]^{44}$.

\footnotetext{
${ }^{38}$ Cortesão, 1951, 138.

39 Astrain, 1913: 629.

${ }^{40}$ Gandía, 1939.

${ }^{41}$ Pastells, 1912, 119.

${ }^{42}$ Cortesão, 1951: 162 ss.

43 Jensen, 2009: 237.

${ }^{44}$ Ibíd: 236.
} 
Muitos índios fugiam dos maloqueiros e dos encomendeiros e se refugiavam nas reduções. Na versão de Washington Luís ${ }^{45}$ a bandeira de Manuel Preto chegou a Cidade Real para resgatar por via pacífica os índios fugitivos que, mormente, estariam foragidos nas reduções de Loreto e Santo Inácio. O historiador português Jaime Cortesão (1958) dá a entender que os jesuítas das reduções acolhiam índios que integravam as bandeiras, retinham-lhes as armas para organizar a defesa das reduções. No período de 1615 a 1623, o provincial do Paraguai, padre Pedro de Oñate, chegou a proibir aos missionários a pregação contra o serviço pessoal e estimulou a organização de reduções no Tape (1626-1640), entendido como espaço neutro, sem a presença de espanhóis e bandeirantes. Neste espaço de tempo, os missionários do Guairá centraram sua ação em torno da organização interna das reduções, do pleito da vinculação direta da encomenda dos índios com o rei, da maior autonomia das reduções em relação às vilas dos espanhóis e da defesa dos índios diante das investidas bandeirantes. Esta postura certamente lhes exigiu maior cumplicidade com os índios, na tentativa de trazêlos para si, como estratégia de aproximá-los a uma base de vida comum e unir horizontalmente os diferentes lugares por eles vividos. Com isto, as missões do Guairá foram constituindo uma forte base territorial.

Com o apoio do padre Diogo de Torres, que era contrário à política adotada para a Província Jesuítica do Paraguai pelo provincial que o antecedeu, Pedro de Onãte, e, sobretudo, a partir da licença concedida pelo governador do Paraguai, Manuel de Frias, em julho de 1622, as missões do Guairá adquiriram novas dimensões. Os conflitos, as dissensões, a mobilidade fronteiriça dos bandeirantes e as fronteiras incertas ensejavam a ocupação de territórios para garantir o seu uso e a preservação do seu potencial humano. Neste sentido, o texto do governador parece não deixar dúvida:

[...] puedan entrar a la dicha Provínçia de yndios nombrados Taiaobas y otros qualesquer que estuvieron en aquella comarca y atraellos, reduçillos y assentallos en la Parte y sitio que a los Padres paresiere mas a proposito y combiniente, para que los tales índios que se reduxeren se puedan conservar mejor y mas bien sustentados y alimentados [...] pueden permanecer y ser enseñados e yndustriados en las cosas de nuestra sancta fee catholica [...] y que se provea lo que mas combenga al serviçio de Dios y de su Magestad $[\ldots]^{46}$.

A delegação de poderes aos jesuítas de reunir os nativos em sítios missioneiros para conservá-los na fé para o serviço de Deus e da coroa parece ter sido o incentivo básico que permitiu a expansão da sua obra missionária no Guairá. Assim, de 1622 a 1628 foram organizados mais 12 povoados, que partindo das reduções do Paranapanema, Loreto e Santo Inácio, se estenderam pelos vales dos rios Tibagi e Ivaí até atingir as cabeceiras e a foz do Iguaçu. Apoiados pelos caciques aliados das terras de Tayaoba, os padres da Companhia conseguiram a adesão dos índios campeiros, que possivelmente representam uma parcialidade Kaingang, até alcançarem os Gualachos no ponto mais avançado em direção ao litoral Atlântico. Desenhou-se, desta forma, uma fronteira sinalizadora do território missioneiro do Guairá, que foi se configurando com a apropriação do espaço e a redução dos povos nativos em povoados para defendê-los do serviço pessoal dos encomendeiros e, sobretudo, dos movimentos fronteiriços dos bandeirantes.

\footnotetext{
${ }^{45}$ Luís, 2004: 350-351.

${ }^{46}$ Cortesão, 1951: 175.
} 
O território missioneiro do Guairá pode ser observado, a partir das fontes documentais que reproduzem a memória escrita da época, como resultado histórico das decisões tomadas nas esferas do poder político e religioso e das iniciativas jesuíticas de reunir os povos nativos em um tipo de organização social que pudesse contemplar os interesses da coroa e da igreja, quiçá da Companhia de Jesus, frente os atores sociais promotores de desmandos e da inquietude social. Coube aos jesuítas, enquanto sujeitos da nova modelação social e espacial a hierarquização do espaço e da sociedade e a iniciativa da defesa das fronteiras do território missioneiro. A defesa pressupunha a escolha do inimigo. E o inimigo maior passou a ser o mameluco, ao qual se tributaram atos anti-humanos, de barbárie e movidos pelo demônio, que na apologética jesuítica representa a causa de todos os males. Montoya, em sua carta anua de $1628^{47}$ qualifica os mamelucos como "gente belicosa e carniceira" e "gente desalmada, tanto assim que matam os índios como se fossem animais". Na "Relação feita pelos padres Justo Mancilla e Simão Masseta ao Rei e ao Provincial sobre os estragos causados pela grande bandeira de Raposo Tavares às missões do Guairá”, publicada por Jaime Cortesão $^{48}$, as referências à barbáries cometidas pelos bandeirantes são recorrentes. Este documento, básico para o estudo das reduções do Guairá, revela as táticas usadas para subornar as leis, de lograr a tolerância das autoridades coloniais e fazer guerra.

A omissão das autoridades foi denunciada pelo provincial Nicolas Duran (16231629), que alertou que "nenhum padre, ainda que seja superior, procure dedicar muita amizade e comunicação com os governadores, pelos danos que se têm experimentado...” ${ }^{49}$. Luiz Céspedes e Xeria, governador de 1625 a 1631, tinha estreita relação com São Vicente, onde sustentava negócios particulares, em documento ${ }^{50}$ que relata a sua viagem daquela vila às reduções do Guairá alega ter havido descaso dos jesuítas em relação ao pedido que lhes fez de reduzir os índios em povoados para protegê-los das bandeiras portuguesas. Insinuou anda que os missionários do Guairá eram usurpadores das possessões da coroa e de fazerem pouco caso dos índios, colocando-os em regime servil. Os encomendeiros do Guairá, que se aliaram a Xeria contra os jesuítas, passaram a ser referidos nas fontes textuais jesuíticas como desordeiros preguiçosos e mentirosos, entre outros atributos.

O desafio dos padres da Companhia era de apresentar às autoridades, do império dual e da igreja, que era necessária uma intervenção política no Guairá para conter a dizimação dos povos nativos e conter a vulnerabilidade da fronteira. A partir daí advogaram com veemência a liberdade dos índios, buscando um território missioneiro livre da presença dos colonos espanhóis e das incursões paulistas. Em carta dirigida ao procurador geral das Índias, no ano de 1627, o provincial do Paraguai, Nicolas Duran, denunciou as ações devastadoras dos bandeirantes e solicitou a sua intervenção junto à coroa para dar solução ao problema da escravização dos índios ${ }^{51}$. Com expedição de Cédula Real em 1627, Filipe IV ordenou que se aplicasse castigo adequado aos promotores dos atos criminosos. Letra morta diante da indecisão se a aplicabilidade da lei caberia às autoridades coloniais portuguesas ou espanholas, as reivindicações à corte

\footnotetext{
${ }^{47}$ Cortesão, 1951: 270, 281 e 335.

${ }^{48}$ Ibíd: 310-339.

${ }^{49}$ Schallenberger, 1997.

${ }^{50}$ AGI, 74, 4: 15.

${ }^{51}$ Pastells, 1912: 409.
} 
de uma intervenção jurídica e política se intensificaram, alcançando expressão com o provincial que sucedeu Duran, com o padre procurador da Companhia nas Índias Ocidentais, com o bispo de Assunção, Frei Cristóbal de Aresti, entre outras autoridades $^{52}$. Os padres do Guairá Justo Mancilla e Simão Masseta, que acompanharam os índios capturados pela bandeira de 1628/1629, visando a sua libertação, apresentaram a sua "Relación de los agravios hechos por los portugueses de San Pablo a las reducciones del Guairá" ${ }^{3}$ ao Governador Geral do Brasil. Antes já haviam protocolado junto ao Ouvidor Geral do Sul, no Rio de Janeiro, queixa-crime contra os paulistas. O Governador Geral supostamente acatou as demandas dos jesuítas e publicou provisão, em dezembro de 1629, pela qual os índios deveriam ser libertados e os descumprissem a ordem severamente castigados.

Segundo Jaime Cortesão ${ }^{54}$ os bandeirantes agiam em favor das autoridades coloniais portuguesas, uma vez que entendiam estar restituindo os territórios da colônia, ocupados pelos espanhóis. Por outro lado, contra os jesuítas pesava a acusação que eles armaram os índios para combater os bandeirantes, daí porque a invasão das reduções. Efetivamente Montoya havia feito petição ao Rei para aramar as reduções contra os ataques paulistas $^{55}$. Justo Mancilla e Simão Masseta alegaram, no entanto, que a invasão das reduções se deu porque era mais cômodo recrutar índios já reduzidos do que os dispersos nos sertões ${ }^{56}$.

Enquanto os conflitos e os embates diplomáticos persistiam em torno da liberdade dos índios e do território missioneiros do Guairá, o governador do Rio da Prata, Francisco de Céspedes, entregou em 1626, em nome do rei e seu, "com ampla liberdade, sem limitação e restrição nenhuma”, ao encargo da Companhia de Jesus a redução dos índios das províncias do Uruguai ${ }^{57}$. A busca de um espaço imune da manobra de forças das autoridades coloniais, omissas ou coniventes com os interesses dos bandeirantes e dos colonos espanhóis, se apresentava como fronteira aberta para a constituição do território missioneiro. A obra evangelizadora, com a fundação de reduções no Uruguai, nas imediações dos rios Piratini e Ijuí, iniciada em 1626, foi precedida pelos trabalhos apostólicos do padre Roque Gonzáles de Santa Cruz, com uma primeira incursão no Tape em 1616 e intensificada a partir de 1623. Destas incursões do padre Roque resultou um diagnóstico, apresentado ao governador Céspedes, das dificuldades de se fazer missão na outra banda do rio Uruguai (Tape). Na certificação dada ao Rei em 1652, o vice-provincial do Paraguai, Diego de Boroa, registra que diante dos perigos enfrentados pelos missionários o governador do Rio da Prata havia disposto soldados para combater os rebeldes e auxiliar na redução dos demais. Segundo a fonte textual, os índios reduzidos foram armados para a defesa e, referindo-se ao ano de 1635, certifica que do apoio inicial das autoridades restam, tão somente, os proventos dados pelos provinciais e pelos colégios da Companhia para

\footnotetext{
52 Ibíd: 409, 456, 467.

${ }^{53}$ Cortesão, 1951: 310-339.

${ }^{54}$ Ibíd, 1958: 147 ss.

${ }^{55}$ Vianna, 1970: 394 e 395.

${ }^{56}$ Cortesão, 1951: 319.

${ }^{57}$ Vianna, 1970, 11.
} 
edificar as reduções, sustentar seus índios reduzidos e manter a defesa contra os inimigos rebeldes de São Paulo ${ }^{58}$.

Se antes os pleitos dos provinciais do Paraguai e dos padres das missões do Guairá já advogavam a necessidade de uma ação política para estabelecer uma fronteira entre colonos e bandeirantes em relação aos jesuítas e guaranis, com a Congregação Provincial dos jesuítas do Paraguai, 7 de abril de 1637, a defesa dos índios, das fronteiras e do território missioneiro teve nova envergadura. Resultou do evento que foram destacados como procuradores da província para atuarem junto ao papa e ao rei os padres Francisco de Díaz Taño e Antônio Ruiz de Montoya, que conseguiram do papa Urbano VIII, com intervenção do Geral da Companhia, a reafirmação das declarações anteriores que proviam a proibição de escravizar índios, e de Felipe IV um conjunto de instruções às autoridades coloniais, que previam castigos às malocas e a devida proteção das populações nativas ${ }^{59}$.

No Tape as bandeiras de Antônio Raposo Tavares (1636), André Fernandes (1637-1638) e Fernão Dias Pais (1639) haviam desencadeado ações similares às desenvolvidas no Guairá e no Itatim, onde a redução dos nativos se iniciara em 1631. Pelas informações do padre Pablo Benavides, da invasão das reduções de Jesus Maria, Santa Ana, São Joaquim, Santa Tereza e São Cristóvão resultaram a destruição dos povoados e mais de 30.000 índios levados em cativeiro. Temendo igual sorte, os jesuítas e os índios reduzidos de São Miguel, Santo Tomé, São Cosme e Damião e Santos Apóstolos São Pedro e São Paulo viram-se obrigados a fugir dos seus sítios ${ }^{60}$. Em função disso, decidiram concentrar as milícias guaranis na costa do rio Uruguai, para fazer frente às possíveis expedições paulistas. As Cartas Anuas de 1637-1639 referem as milícias das reduções, que fizeram frente aos bandeirantes, vencendo-os nas batalhas de Caazapa Mirim, em 1638, e na de Caazapa Guaçu, em 1639. Em 1641 defrontaram-se com a expedição de 400 portugueses e 2.700 tupis e com canoas, armas e flechas conseguiram estancar o avanço bandeirante na batalha de Mbororé, na qual renderam as tropas inimigas ${ }^{61}$.

O recuo dos jesuítas e dos índios das missões, questionado pelas autoridades eclesiásticas e da colônia espanhola, pode ser visto ao mesmo tempo como uma necessidade e como estratégia para evidenciar a vulnerabilidade das fronteiras do império espanhol na região platina, defendidas quase que exclusivamente pelas milícias guaranis, e estratégia para a definição do território das missões.

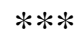

A experiência missioneira do Guairá, seguida pela do Uruguai (Tape) e do Itatim confere a província jesuítica do Paraguai um significado particular. O cruzamento dos interesses e poderes verticais promoveu o conflito étnico, o desencontro das frentes da conquista e a instabilidade territorial. A ação evangelizadora dos jesuítas revelou a sua

\footnotetext{
${ }^{58}$ Ibíd: 30.

${ }^{59}$ Schallenberger, 2006: 100.

${ }^{60}$ Vianna, 1970: 325 e 326.

${ }^{61}$ Porto, 1954: 180-191.
} 
capacidade de estabelecer relações horizontais, de aproximar povos e lugares de um projeto societário inovador nas esferas do trabalho, da economia, do ambiente, da religião e da linguagem. Os índios, sobretudo os Guarani, demonstraram diante das diferentes situações de contato e de conflito a plasticidade incrível de suas estruturas culturais. Mitos e crenças, como as apresentadas por Montoya ${ }^{62}$, que veneravam os ossos dos mortos, cujos corpos são sem alma, acreditavam nos animais com alma, porém sem vida social, e na palavra como manifestação da alma-boa encarnada na gente $^{63}$, que tem vida social e que vive em sistema de parentesco, isto é de afinidade, de proximidade e de prestação de favores, certamente são elementos que se mantêm vivos na cultura guarani até hoje, mas que historicamente sofreram sentidos agregados pelas situações de contato. De infiel a cristianizado, de rude selvagem a agricultor, criador de gado, cavalos, ovelhas e animais domésticos, de guerreiro selvagem a miliciano e de incapaz a hábil artesão, dentre tantos outros atributos, o guarani foi assumindo centralidade nas fontes textuais de acordo com os interesses em jogo. Alvos enquanto mão de obra, ou sujeitos integrados na construção de uma utopia colonial, na defesa do território missioneiro e das fronteiras do Império espanhol, os Guarani sobrevivem e se reconstroem como povo que se referencia a partir da fronteira cultural, possível de ser identificada pelo seu modo de ser e viver a espacialidade, mesmo que alterados pelas situações de contato.

Em suma, a província jesuítica do Paraguai desenvolveu um processo de evangelização e de socialização no Guairá, no Itatim e no Uruguai que definiu um estilo jesuítico-guarani de fazer missão, fundado em relações horizontais e dialógicas, sem renúncia à apologética da salvação, e no princípio da libertação (do estado da natureza, do demônio, dos inimigos escravocratas) enquanto possibilidade de conversão e de constituição de um território de missioneiro. O recuo da fronteira do território missioneiro em construção, consubstanciou uma maior unidade territorial, construída a partir da solidificação da defesa, das relações de poder e da organização interna do complexo missioneiro dos trinta povos da bacia do Prata. A fronteira da evangelização foi se convertendo em fronteira política na medida em que os interesses verticais dos impérios coloniais foram definindo seus limites territoriais. Assim, às missões foi conferido um caráter de instituições de fronteira e o território das missões passou a ser entregue, progressivamente, a sorte das negociações políticas e dos tratados. Nunca deixou de ser, no entanto, o território missioneiro, apesar da sua fragmentação e incorporação pelos impérios coloniais e, posteriormente, pelos estados nacionais.

\section{Referências:}

AGI Testemonio de una relación de sucesos ocorridos al gobernador del Paraguay don Luís de Déspedes Xeria (...) AGI (74) 4: 15.

AGI Souza, Luís de. 1611, Testemonio y trasunto en castellano de la comisión que el gobernador de San Pablo del Brasil, don Luis de Souza, dio en Aldea de Fuerte a 25 de agosto (1611) a los caciques de las aldeas de aquella villa para que a costa suya fuesen con sus indios a los parientes que tennian en el Certon de Guaira con objeto de que ayudasen a labrar las minas que teniam los portugueses. Parambú

\footnotetext{
62 Montoya, 1985: 52.

${ }^{63}$ Cadogan, 1959: 19 ss.
} 
- 12 de noviembre de 1611. Archivo General de Indias - AGI, Estante 74, Cajón 6, Legajo 21.

Aguilar, Jurandir Coronado (2002), Conquista espiritual - a História da evangelização na Província Guairá na obra de Antônio Ruiz de Montoya, S. I. (1585-1652). Roma: Editrice Pontifícia Università Gregoriana.

ARSI - Archivum Romanum Societati IESU. Paraquaria I, p. 57-61.

Astraín SI, Antonio (1913), Historia de la Compañia de Jesus em la asistencia de Espana. Vol. IV, T, 4, Madrid: Administración de Razón y Fé.

Alvear, Diogo de (1836), Relación Geográfica y histórica de la Província de Misiones. Buenos Aires: Imprenta del Estado.

Becker, Berta. K. (1997), Amazônia. 5 ed. São Paulo: Ática,.

Bourdieu, Pierre (1982), A economia das trocas simbólicas. São Paulo: Perspectiva.

Cadogan, Leon (1959), Ayvu Rapyta - Textos míticos de los Mbyá-Guarani del Guairá. São Paulo: FFCL/USO.

Caleffi, Paula (2002), Uma introdução ao universo Guarani. In: Schwingel, Lúcio Roberto (org.). Povos Indígenas e Políticas Públicas da Assistência Social no Rio Grande do Sul. Subsídios para a construção de políticas públicas diferenciadas às comunidades Kaingang e Guarani. Porto Alegre: Secretaria do Trabalho, Cidadania e Assistência Social - RS.

Cortesão, Jaime (1951), Jesuítas e bandeirantes no Guairá. MCA I. Rio de Janeiro: Biblioteca Nacional.

Cortesão, Jaime (1958), Raposo Tavares e a formação territorial do Brasil. Rio de Janeiro.

Gandía, Enrique de (1939), Francisco de Alfaro y la condición social de los índios: Rio de la Plata, Paraguay, Tucumán y Peru (siglos XVI y XVII). Buenos Aires: El Ateneo.

Haubert, Máxime (1980), A vida quotidiana no Paraguai no tempo dos jesuítas. Trad. Virginia Mota, Lisboa: Livros do Brasil.

Hernández, Pablo (1913), Misiones de Paraguay: organización social de las doctrinas. Barcelona, Gustavo Gili.

Holanda, Sérgio Buarque de (1957), Caminhos e Fronteiras. Rio de Janeiro: José Olympio.

Jaeger, Luiz G. (1957), La Compañía de Jesus en el antiguo Guairá (1585-1631). Pesquisas, Porto Alegre, v. 1, p. 94-121.

Koselleck, Reinhart (1992), Uma história dos conceitos: problemas teóricos e práticos. In: Estudos Históricos, n. 10, p.134-146.

Leal, Maria Luísa (2001), Autobiografia e memória em espaços literários pós-coloniais. In: IV Congresso Internacional da Associação Portuguesa de Literatura Comparada Évora. Disponível em: http://www.eventos.uevora.pt/comparada/VolumeI/AUTOBIOGRAFIAEMEM ORIAEMESPACOSLITERARIOSPOSCOLONIAIS.pdf. 
Leite, Serafim (1938 - 1950), História da Companhia de Jesus no Brasil, I-X. Lisboa: Portugália / Rio de Janeiro: Civilização Brasileira.

Luis, Washington (2004), Na capitania de São Vicente. Brasília: Edições do Senado Federal.

Martins, Romário (1940), Bandeiras e Bandeirantes em Terras do Paraná. Curitiba, Guaira.

Mateos SI, Francisco (1944), “Antecedentes de la entrada de los jesuítas en las misiones de América. [1538-1575]”, Missionália Hispânica I (1944), 110-116.

Monfort. http://www.montfort.org.b > em 17/06/2011.

Mora Mérida, José Luis (1971), La sociedad paraguaya hacia 1625. Anuario de Estudios Americanos. Sevilla: Universidad de Sevilaa/Consejo Superior de Investigaciones Científicas, v. 28.

Pastells SI, Pablo (1912), História de la Compañia de Jesus en la Província del Paraguay según los documentos del Archivo General de indias. T. I, Madrid: Archivo General de indias.

Pompa, Cristina (2001), Profetas e santidades selvagens. Missionários e caraíbas no Brasil colonial. Revista brasileira de História. [online], vol.21, n.40, pp. 177193.

Porto, Aurélio (1954), História das missões orientais do Uruguai. Vol. I-III, Porto Alegre: Selbach.

Quarleri, Lia (2009), Rebelión y guerra em las fronteras del Plata - Gauaraníes, jesuítas e imperios coloniales. Buenos Aires: Fondo de Cultura Económica.

Santos, Milton (2006), A natureza do espaço. Técnica e tempo. Razão e emoção. São Paulo: Hucitec.

Schallenberg, Erneldo org. (2010), Fronteiras culturais e desenvolvimento regional: novas visibilidades. Porto Alegre: Evangraf.

Schallenberg, Erneldo (2006), O Guairá e o espaço missioneiro: índios e jesuítas no tempo das missões rio-platenses. Cascavel: Coluna do Saber.

Schallenberg, Erneldo (1997), A integração do Prata no sistema colonial: colonialismo interno e missões jesuíticas do Guairá. Toledo: EdT.

Techo, Nicolas del (2005), História da la Província del Paraguay de la Compñía de Jesús. Asunción: Centro de Estudios Paraguayos Antonio Guasch/FONDEC.

Vianna, Helio (1970), Jesuítas e bandeirantes no Uruguai (1611-1757) - MCA IV. Rio de Janeiro: Biblioteca Nacional. 